\title{
Six functions of bilingual EFL teacher talk: Animating, translating, explaining, creating, prompting and dialoguing
}

\author{
Ross Forman, University of Technology Sydney \\ Published in RELC Journal 2012, 43(2): 239-253
}

\begin{abstract}
'Teacher talk', which remains a primary feature of much education, plays a crucial role in EFL contexts where exposure to the L2 is often confined to the language classroom, and where local teachers generally share L1 with their students. The present study explores fresh ways of describing the major pedagogic functions of teacher talk across both L1 and L2 in such environments. It seeks to establish broad descriptive categories which can be directly applied by teachers and teacher-educators to the analysis of bilingual classroom practices.
\end{abstract}

\section{BACKGROUND}

The literature relating to teacher talk itself is vast, but until recently has paid relatively little attention to the role of L1 in L2 pedagogy, particularly in the foreign language classrooms where the majority of the world's formal L2 learning takes place.

However, in 2009, we saw publication of the first full-length volumes dealing with the role of L1 in L2 learning. These were four in number: one monograph by Song and Andrews exploring EFL pedagogy in China; another by Butzkamm and Caldwell concerned with foreign language teaching (FLT), which hailed the end in sight of 'the mother tongue taboo'; a collection of papers edited by Turnbull and O'Daley Cain (2009a) again concerned mainly with FLT; and a special issue of the International Journal of Bilingual Education and Bilingualism which focussed on classroom codeswitching, primarily in post-colonial contexts.

In the East and S E Asian region, although the use of L1 is officially still discouraged or proscribed in many countries, small but growing support for change has been found in China (Song and Andrews 2009); Taiwan (Raschka, Sercombe and ChiLing 2009); Japan (Myojin 2007); Korea (Liu, Ahn, Baek and Han, 2004); and Indonesia (Zacharias 2004).

In relation to Western foreign language classrooms, an interesting comparison may be made. Both Macaro (2000, 2009), for example, and Butzkamm (2003; Butzkamm and Caldwell, 2009), have consistently argued against the appropriacy of 'pure' Direct Method and in favour of considered L1 use for FLT.

Despite the increasingly positive theorisation of the role of L1 in L2 learning noted above, however, there remain very few empirical studies which capture actual 
teacher talk in such contexts (Macaro, 2009: 40). Consequently, Üstünel and Seedhouse have called for investigation into "how pedagogical focus and language choice are related in the teaching of other languages" (2005: 322). Their voices are joined by others, including Carless (2008), and Turnbull and Daley-O'Cain (2009b), with the latter arguing in favour of a "full-scale re-evaluation" of the role of L1 in L2 learning (p. 14). It is to these calls that the present study seeks to respond.

\section{METHODOLOGY}

The study is conducted in the English Department of a medium-size provincial Thai university, here called 'Isara', which is the former workplace of the researcher. It forms part of a larger project conducted at that institution 2002-2004 (Forman, 2005, 2008, 2010, 2011).

\section{Teachers}

There were nine teachers in the study: five were female, four male. Eight were native Thais, and one was Anglo-Australian. All teachers were qualified at Master's level; and three possessed doctorates. Their teaching experience ranged from 3 to 38 years. All teachers were expert speakers of both Thai and English. In setting up the present study, I had initially contacted my former head of department in Thailand to seek her assistance in obtaining volunteers for the study: nine teachers accepted my invitation, including four already known to me. In this study, I will refer to teachers by their selfselected pseudonym, along with the honorific 'Ajarn' ('lecturer) or 'Doctor'; thus, for example, Ajarn Nanda.

\section{Students}

Students fell into two distinct groups: six English-major classes, and four non Englishmajor classes. The language proficiency of English-major students was predictably high, at bands 5-6 of IELTS; whereas the proficiency of non-major students was relatively low, generally at bands 2-3 of IELTS.

\section{Research design}

The naturalistic approach taken by the present study was chosen as one which could most clearly represent what was seen to happen in these Thai EFL classrooms. In the larger project from which this study is taken, a total of 19 hours' classroom observation data was obtained. Additionally, each teacher was interviewed on three or four occasions, producing 24 hours of interviews. In the present study, it is classroom data alone which is analysed.

All Thai language spoken by teachers was transcribed and translated into English. Selected parts of lessons where teachers spoke in English were transcribed, and 
other parts summarized. Audio-tapes for each teacher were played in conjunction with the researcher's field notes and both English and Thai transcriptions in order to build an overview of pedagogy.

An initial analysis of lesson observation data was done through categorizing teacher behaviour by pedagogic function according to L1 and L2 use. By testing common patterns found in one lesson against others of this study, it became possible to identify distinct categories which initially came to 19 in number, and included, for example, giving instructions, correcting, initiating, explaining grammar. Various attempts were then made to relate the functions thus identified to existing patterns and descriptors such as the IRF sequence (Sinclair and Coulthard 1975); Christie's (following Bernstein's) pedagogic and regulatory registers (1994); the Communicative Orientation of second Language Teaching scheme (COLT - Allen, Fröhlich \& Spada 1984; Spada \& Fröhlich 1995); the latter's development into the Functional Language Alternation Analysis of Teacher Talk framework (FLAATT - Kim 2001; Kim and Elder 2005); Canagarajah's (1995) identification of seventeen micro functions of teacher L1 use; a twelve-part scheme offered by Üstünel and Seedhouse (2005), as well a Thai-based study of teachers' L2 instructions (Watson-Todd, Chaiyasuk and Tantisawetrat, 2008). However, the categories used by existing studies were found to be to be suited to particular contexts (EFL, ESL, FLT); to be lacking a bilingual dimension; or to focus at a level of detail which although appropriate for research purposes, would be difficult for teachers to apply to an analysis of their practice. With regard to the IRF, for example, it was found that while Step 1 (Initiate) seemed familiar in these Thai classrooms, Step 2 (Respond) was sometimes absent, and Step 3 (Feedback) could either be absent, or more commonly was of a different (bilingual) nature and (non-evaluative) function. The FLAATT, on the other hand appears to be well suited to the analysis of bilingual lessons. But its level of detail was greater than that sought in the present study (30 'teaching acts', or functions, in Kim [2001], reduced to 16 in a later paper by Kim and Elder [2005]).

In general, existing analyses of classroom L1 use have aimed to document the whole range of classroom functions. In this light, Ferguson has provided a useful framing of three macro functions $(2003,2009)$ :

- for constructing and transmitting ideas/knowledge

- for interpersonal and humanistic reasons

- for classroom management (in the sense of student behaviour).

My interest here will be confined to the first named, which will be called the pedagogic function; affective and management functions will not be considered. It may be recalled that the aim of this enquiry is to establish descriptive categories which are theoretically robust, and which are broad enough to be readily applied by educators in analyzing their 
own and others' lessons. Accordingly, the 19 patterns initially identified in the present study were reduced to six broad categories of pedagogic function, and the research question posed is:

What are the principal pedagogic functions of $L 1$ and $L 2$ teacher talk in the EFL context of a Thai university?

\section{DISCUSSION}

The six pedagogic functions established here will first be outlined briefly, and then exemplified by classroom extracts.

Function 1, Animating, refers to the teacher's oral rendering of written English, which represents for students - particularly in low-tech environments - an opportunity to hear how written L2 actually sounds. The term is borrowed from Goffman (1974), although used more narrowly here.

Function 2, Translating, occurs when the teacher translates words or phrases from L2 into L1.

Function 3, Explaining, can occur in L1 or L2: principally when the teacher provides metalinguistic information concerning the grammar, meaning, usage or culture of the L2 - explaining what is; but also when s/he gives instructions in the classroom explaining what to do.

Function 4, Creating, refers to teacher use of L2 for the purpose of meaningbased communication. It is connected to the notion of 'comprehensible input' which has retained widespread popularity amongst language teachers. But the new term Creating has been coined for three reasons. First, the notion of comprehensible input may suggest a necessary correspondence between what the teacher does - 'gives input' - and what the student does - 'comprehends'; in other words, that a desire to create comprehensibility of itself assures success (Gass and Selinker 2001). Second, there are of course serious concerns about the 'input' metaphor itself and its 'learner as machine' basis (Ellis 2001). And thirdly, the new term seeks to capture something of the richness of a teacher's "message abundancy" (Gibbons 2003), which here is taken to include strategies such as paraphrase, exemplification, personalization and localization, the creative dimensions of which are sometimes underestimated.

Functions 5 and 6 are termed Prompting and Dialoguing. Both refer to the teacher's initiative to engage students in whole-class response, and here I use the classic distinction between two types of teacher-student interaction. The first is mediumoriented, focussing on language itself, here termed Prompting; and the second is message-oriented, concerned with the exchange of meaning, here termed Dialoguing.

The following section will explore in more detail how the 6 functions were seen to play out in the present study. Transcription conventions appear as an Appendix. 


\section{(1) Animating}

Animating was a staple function observed to occur across all classes of the study when teachers read aloud to students parts of the prescribed monolingual textbooks.

Exemplification is provided in the context of the second function, Translating (see Extract 1 below). It might be noted that in providing a local performance of a global textbook, this function affirms the teacher as an expert 'channeller' of L2, and thus represents a key professional accomplishment. In my experience of working with teachers in hundreds of EFL classes across the S E Asian region, I have often noted the pride with which L2 Animating is displayed, as well as the anxiety sometimes produced by such performance.

\section{(2) Translating}

A fundamental and frequent use of L1 in this study was the direct translation of written English text into spoken Thai.

The following example comes from Dr Patcharin's class of non-major students. The lesson was based on the set text Passages 1, by Richards and Sandy (1998: 93), Unit 10: 'The Art of Complaining'. (Words from the textbook appear in single inverted commas.)

Extract 1. Translating and Animating - Dr Patcharin

animate translate

\begin{tabular}{|c|c|c|c|}
\hline 1 & 'You have the right to be on a flight.' & $\sqrt{ }$ & \multirow[b]{3}{*}{$\checkmark$} \\
\hline 2 & คือ เค้าต้องได้ไป เที่ยวบิน & \multirow{4}{*}{$\sqrt{ }$} & \\
\hline & This means that you must be able to be on the flight. & & \\
\hline 3 & 'You have booked.' & & \\
\hline 4 & ที่ไดบุคเอาไว้ & & \\
\hline & You have booked. & & $\checkmark$ \\
\hline
\end{tabular}

Here is seen a protocol which was common across the study as a whole: the association of Animating and Translating. That is, the teacher would read aloud the written L2 text, and translate it by word or phrase into L1 - a technique also called 'English-annotation' in Lin's studies of Hong Kong English classrooms (e.g. 1996). Through it, a link is provided between the written L2, which is animated - rendered orally - by the teacher, and then translated - conveyed into L1. Translating has been traditionally discouraged in ELT, principally because it is seen to reduce students' attention to and experience of L2. But on the other hand, this practice may be seen to provide, as here, speedy, 
accurate understanding of L2 - and presumably on the part of all students (see also G. Cook, 2010).

\section{(3) Explaining}

As noted earlier, Explaining by the teacher can take two forms: (a) giving metalinguistic information concerning the sounds, grammar, meaning, usage or culture of the L2 explaining what is; or (b) giving instructions in the classroom - explaining what to do. Explaining could happen in L1 or L2. Here are two examples of the metalinguistic type of Explaining which relate in turn to pronunciation and grammar. The first is taken from Ajarn Laksana's beginner class of (non-major) Nursing students. In the first example, the teacher had introduced the topic in English, and then entered into some brief drilling of vocabulary items. When she came to the phrase 'a box of chocolates', the students did not successfully link the second and third words, which occasioned the following explanation in Thai:

Extract 2. Explaining in L1 - Ajarn Laksana

1 มี linking ด้วยนะคะ อย่าลืมนะ There is linking too, don't forget. Don't forget

2 ถ้าคำหน้าจบด้วยพยัญชนะ คำหลังขึ้นต้นด้วยสระ เวลาออกเสียง เราจะต้องลากเสียงเชื่อมโยงกัน

If the first word ends with a consonant sound, and the next word begins with a vowel sound, when we pronounce these words, we must join the sounds together.

3 เราเรียกว่า linking sound นะคะ

We call it 'linking sound', okay?

4 เพราะฉะนั้น box ลงท้ายด้วย $x$ ใช่มั้ขคะ of ขึ้นต้นด้วยสระ เพราะฉะนั้นต้องอ่านว่า So, 'box' ends with ' $x$ ', right. 'of' begins with a vowel. So we must pronounce:

5 a box of อีกที

'a box of' once again

Explaining can also occur through the medium of L2. Such a choice clearly offers students greater exposure to the target language, and such exposure takes place in a meaningful context of 'classroom language work'. On the other hand, there are limitations inherent in talking about L2 exclusively through the medium of L2, as is well known to any monolingual ESL teacher. 
In the following example, taken from Dr Patcharin's English-major class, explaining of grammar occurs mainly in L2 [lines 2, 5, 7, 8, 11], but is supported at one point by L1 [line 10], as well as by direct translation [lines 3 and 6].

Extract 3. Explaining in L1 and L2 - Dr Patcharin

\begin{tabular}{|c|c|c|c|c|}
\hline & & animate & translate & $\begin{array}{l}\text { explain } \\
\text { L1/L2 }\end{array}$ \\
\hline 1 & $\begin{array}{l}\text { 'Complaining works because companies don't } \\
\text { want dissatisfied customers.' 'Complaining } \\
\text { works'. }\end{array}$ & $\checkmark$ & & \\
\hline 2 & In this case it means: & & & $\checkmark \mathrm{L} 2$ \\
\hline 3 & ได้ผล It works & & $\checkmark$ & \\
\hline 4 & $\begin{array}{l}\text { - uh - 'because companies don't want } \\
\text { dissatisfied customers.' }\end{array}$ & $\checkmark$ & & \\
\hline 5 & Dissatisfied. Satisfied. & & & $\checkmark$ L2 \\
\hline 6 & พอใจ satisfied & & $\checkmark$ & \\
\hline 7 & $\begin{array}{l}\text { You add 'dis'. 'dis' means 'not', right? Not. } \\
\text { 'Dissatisfied' means 'not satisfied' customers. }\end{array}$ & & & $\checkmark$ L2 \\
\hline 8 & 'Not sure you can do it?' & $\checkmark$ & & \\
\hline 9 & $\begin{array}{l}((\text { means })) \text { If you are not sure you can do it. } \\
\text { That's the complete sentence. }\end{array}$ & & & $\checkmark$ L2 \\
\hline 10 & ประโยคที่เต็มก็คือ The complete sentence is: & & & $\checkmark$ L1 \\
\hline 11 & $\begin{array}{l}\text { If you are not sure you can-uh, if you are not sure } \\
\text { you can do it. }\end{array}$ & & & $\sqrt{ } \mathrm{L} 2$ \\
\hline
\end{tabular}

And lastly, here is an example of the second type of explaining, explaining what to do, which occurs in L2 at the start of Ajarn Murray's class of (non-Major) Science students.

Extract 4. Explaining in L2 - Ajarn Murray

1 Ok. Today, we'll start looking at Unit 7, page 37. Unit 7, page 37.

2 Now [3] please open your books ... quickly, page 37. Quickly, I'm not going to use the books now, ok? I'm not going to use the books now. I just want you to look at the picture. 
This use of L2 to convey simple classroom instructions is of course a practice commonly recommended to beginning language teachers, and can, as here, provide ready exposure and practice. On the other hand, if the task is complex or abstract, then exxclusive use of L2 can pose significant problems in explanation; in such cases, Nation's comment (2003: 5) seems apt, that 'It is foolish to arbitrarily exclude this proven and efficient means of communicating meaning.'

\section{(4) Creating}

As indicated above, the term 'Creating' refers to the teacher's use of L2 for meaningbased communication. Most lessons observed in this study consisted of accessing written texts taken from prescribed textbooks by animating them, and then explaining and/or translating. But creating goes further to engage students in L2 which expands the content and associated language beyond what is given by the textbook. This 'created' L2 is thus both newly heard and solely in the oral mode.

How then does teachers' Creating work to effectively convey meanings in L2? It may be seen to do so in three ways: through choice of semantics, lexico-grammar, and extra-linguistic semiosis such as gesture or image. Each of these will now be briefly explored.

\section{a. Semantics}

The contextual nature of meaning is critical here, for in the process of Creating, the teacher can draw upon what s/he knows of learners' current knowledge in order to make appropriate semantic choices. This was evident in a number of lessons observed: Dr Patcharin, for example, presented familiar Thai, Anglo and Arab world figures as a warm-up for the textbook topic concerning personality types; Ajarn Murray drew upon his knowledge of his students' lives to 'play' with cultural norms (Forman 2011).

The following example of this process is taken from Ajarn Nanda's class where a reading passage had touched on the notion of 'social issues'.

Extract 5. Creating - Ajarn Nanda

1 So what are the possible sides of the issue?

2 Should we move the คลังแสง munitions dump from Pak Ton to another place?

3 Not to be with the community? Right ok.

4 So this is the issue.

5 Or should we more the community? ((humorous voice; students laugh)) Should we move the คลังแสง munitions dump, or should we move the community, okay? So this is the issue. 
Thus, the teacher may be seen to draw on students' existing semantic field in her presentation of fresh L2 input and to thereby embed the target language within students' cultural knowledge. This is a competence which is uniquely available to a bilingual/bicultural teacher, and its expression may be regarded as kind of bilingual intertextuality (Forman 2008).

\section{b. Lexico-grammar}

The Creating function can provide both message simplification and message abundancy. An example follows from Ajarn Laksana's lesson, which was triggered by the appearance of the term 'best-seller' in the monolingual English textbook.

Extract 6. Creating - Ajarn Laksana

1 'Best-seller'....

2 At the moment Harry Potter is the best-seller book.

3 Everybody knows and reads it.

4 The shop-owner got a lot of money from selling this book.

5 So, Harry Potter is the best-seller at the moment.

$6 \quad$ Understand this?

It may be seen that here we have a semantic thread which is formed by lexical devices of simple repetition, endophoric reference, and substitution around the new lexical item of 'best seller'. Following Halliday (1985), we may say that this particular text has a lexical density of approximately $50 \%$, which is higher than that usually found in dialogue, but characteristic of monologist teacher talk in this field. It is also notable that the teacher selects highly frequent lexis, which is more accessible to a range of learners. Moreover, her text differs from everyday spoken English in that it is less grammatically intricate, and in that respect less cognitively demanding: the number of clause complexes is low, with the two instances limited to simple parataxis (making use of the conjunctions 'and' and 'so') rather than hypotaxis. The cumulative effect of these features is to create congruency of language and transparency of meaning, and to thereby enhance opportunities for learners to comprehend and learn.

\section{c. Extra-linguistic semiosis}

Creating in the present study was not often supported by extra-linguistic semiosis except in the shape of commercial textbooks and their visual illustrations. The latter 
were fundamental to most lessons, but their Amerocentric and monolingual nature sometimes appeared to confuse rather than assist in the conveying of meaning across cultures.

\section{(5) Prompting}

As noted above, this function consists of the teacher's 'medium-oriented' public wholeclass interaction with students. The first example below is taken from Ajarn Nanda's advanced English-major class on Critical Reading.

Extract 7. Prompting - Ajarn Nanda

1 T: The author's 'point of view'. What does it mean? What is it about?

2 S: The author's feeling

3 T: The author's ?... feeling. The author's opinions, the author's ? ... attitude. Everything, okay?

((?... indicates high rising tone + pause $))$

The second example of Prompting is taken from Dr Patcharin's class. It occurred as the teacher was working through a written L2 passage in the textbook Passages 1 (Richards \& Sandy, 1998, p. 94). It may be seen that Prompting occurs mainly in L1, but at one point in L2 [line 3]; and that here it is linked to Animating.

Extract 8. Prompting - Dr Patcharin

animate prompt

1 T: 'Would you be afraid of moving to a foreign country?'

2 T: Would you like to answer that question: 'Would you be afraid of moving to a foreign country?'

$3 \mathrm{~T}$ : เข้าใจคำว่า 'afraid of' มั้ย

Do you understand 'afraid of'?

4 T: To be afraid of?

5 T: What does it mean 'afraid of', to be afraid of? Uh?

The two Prompting examples illustrated above suggest that there was value in having the expert language user provide cues of a simple nature which could guide learners just 
enough and not too much in their development of L2. Such interaction in the form of IRF has been the subject of significant criticism for many years (e.g. Barnes, 1976; Lemke, 1990), principally on grounds of its superficiality. However, in the language class, there may be times, as here, when depth of cognition may not be desirable - if it distracts students from achieving transparency of comprehension, or accuracy in production of targeted language forms.

\section{(6) Dialoguing}

Dialoguing is regarded as a 'meaning-oriented' exchange between teacher and students. The sample below (Extract 9) follows a written exercise which had required students to put into order four nominated stages of culture shock (Tourism; Emptiness; Recovery; Acceptance). The teacher then asked students to report their answers in L2, and sought to elicit student explanation of their answers. We pick up the lesson in the last part of the report-back.

Extract 9. Dialoguing - Dr Patcharin

1 T: OK, the acceptance stage. OK. How will you feel in this stage?

2 S: You don't want to go back home.

3 T: You don't want to go back home- why not?! Why not! Uh?!

4 S: ((inaudible to teacher and researcher))

5 T: Why - why! ((laughs)) Why don't you want to go back home!

7 S: ((inaudible to teacher and researcher $)$ )

8 T: Uh?

9 S: จะพูดว่าไงดี What should I say?

10 T: [L] Okay! Say something [L]

11 S: ((inaudible to teacher and researcher $)$ )

12 T: What?

$13 \mathrm{~S}$ : ประมาณว่ายังไงดี เอาภาษาไทยก่อนละกันนะคะ ขอมรับในสิ่งที่แตกต่างภายในประเทศนั้นได้แล้ว ก็จะแบบว่า เอออยู่ได้ How should I say it? In Thai first then. Accept the differences between the countries, then er it's okay to live there.

14 T: Okay. Now you are familiar with the- with the environment. With the people, right? You get to know the people. You know the way around, you- you can do everything by yourself now. Ok. You seem to enjoy living there, right? 
This example was of note because up till now, a major part of the lesson had been the teacher's Prompting of students to display their knowledge of the descriptors provided in the textbook. At this point, however, a student chose to respond 'authentically', inasmuch as her response did not mirror the written text under study, and presumably it therefore represented the student's own voice. The teacher sounded amazed, with her voice increasing in volume and in pitch range (rare occurrences in Thai classrooms). It took six or seven fairly quickly repeated questions in order to elicit a reason from the student. Why does this exchange stand out in my mind? Because it represented a moment in the lesson when a student offered a personal view to which the teacher responded spontaneously with surprise and interest: a 'dialogic' communication.

A second example appears in a different part of Ajarn Nanda's English-Major class cited above in Extract 5 . The teacher had provided a spoken commentary upon a short story 'To an old friend'. At the point where one character reminded the other of his former 'dream' of becoming an astronaut, the teacher turned to the class and asked each student to nominate their own 'dream', a process which engaged students in producing a range of spoken responses in L2, as well as their teacher in building upon these responses.

Such moments of Dialoguing were of significant impact upon the tenor and field of classroom discourse. However, it must be said that they were not often seen in the present study.

\section{Seamlessness of bilingual discourse}

The six pedagogic functions which have been described above are found to be valuable in making sense of the complex production of teacher talk. But while these functions are clearly distinguishable, I would like to emphasis the intricacy and bilingual blending which was seen to occur. The teacher may translate, and then prompt whole class interaction; s/he may explain in L1 or L2; then return to animate the L2 written text, with all this happening in a matter of seconds.

Several examples have already demonstrated two functions operating together. The following text further demonstrates such blending, where four functions (bar creating and dialoguing) are seen to occur. It is taken from Dr Patcharin's class drawn upon earlier, and is based upon the following written paragraph from Passages 1 called 'Getting what you are entitled to'.

Stand up for your rights

You have the right to receive a product you ordered in a timely manner. With airlines, you have the right to be on a flight you've booked. Always demand satisfaction when your consumer rights are violated. (Richard and Sandy 2001: 93). 
Extract 10. Seamlessness of bilingual discourse - Dr Patcharin

\begin{tabular}{|c|c|c|c|c|c|}
\hline & & $\begin{array}{l}\text { ani- } \\
\text { mate } \\
{[\mathrm{L} 2]}\end{array}$ & $\begin{array}{l}\text { tran- } \\
\text { slate } \\
{[\text { L1] }}\end{array}$ & $\begin{array}{l}\text { exp- } \\
\text { lain } \\
\text { [L2] }\end{array}$ & $\begin{array}{l}\text { pro- } \\
\text { mpt } \\
{[\text { L1] }}\end{array}$ \\
\hline 1 & $\begin{array}{l}\text { 'You have the right to receive a product you ordered } \\
\text { in a timely manner.' Uh? 'Timely manner.' }\end{array}$ & $\checkmark$ & & & \\
\hline 2 & หมายความว่าอะไรคะ What does it mean? & & & & $\checkmark$ \\
\hline \multirow[t]{2}{*}{3} & ทันเวลา ในเวลาที่พอเหมาะ & & & & \\
\hline & In time. In the appropriate time. & & $\checkmark$ & & \\
\hline 4 & When you pay, you will get your... product. & & & $\checkmark$ & \\
\hline 5 & If you are- sorry! ((teacher makes mistake $))$ & & & $\checkmark$ & \\
\hline 6 & $\begin{array}{l}\text { 'You have the right'. Uh 'You have the right to } \\
\text { receive a product you ordered.' }\end{array}$ & $\checkmark$ & & & \\
\hline 7 & 'You order'. 'You order' modifies 'a product'. & & & $\checkmark$ & \\
\hline 8 & สินค้าที่เราสั่ง a product you ordered & & $\checkmark$ & & \\
\hline 9 & 'in a timely manner.' & $\checkmark$ & & & \\
\hline 10 & 'With airlines', & $\checkmark$ & & & \\
\hline 11 & for example, 'with airlines' & & & $\checkmark$ & \\
\hline 12 & สายการบิน airlines & & $\checkmark$ & & \\
\hline 13 & $\begin{array}{l}\text { uhh 'You have the right to be on a flight' er 'to be on } \\
\text { a flight'. }\end{array}$ & $\checkmark$ & & & \\
\hline 14 & 'You have booked.' Uh-huh. & $\checkmark$ & & & \\
\hline 15 & 'You have booked', modify 'a flight'. & & & $\checkmark$ & \\
\hline 16 & 'You have the right to be on a flight.' & $\checkmark$ & & & \\
\hline \multirow[t]{2}{*}{17} & คือเค้าต้องได้ไปเที่ยวบิน & & & & \\
\hline & This means that you must be able to be on the flight. & & $\checkmark$ & & \\
\hline 18 & 'You have booked.' & $\checkmark$ & & & \\
\hline 19 & ที่ไดบุ๊คเอาไว้ You have been able to book. & & $\checkmark$ & & \\
\hline 20 & 'Always demand satisfaction.' ((repeated $))$ & $\checkmark$ & & & \\
\hline 21 & คืออะไรคะ What does this mean? & & & & $\checkmark$ \\
\hline 22 & 'Demand' แปลว่า ? 'Demand' means? & & & & $\checkmark$ \\
\hline \multirow[t]{2}{*}{23} & $\begin{array}{l}\text { ต้องการนะคะ ต้องการ } \\
\text { เราต้องแสดงออกถึงความต้องการของเรา }\end{array}$ & & & & \\
\hline & Need, right; need. We must express our need... & & $\checkmark$ & & \\
\hline 24 & ...when you pay. & & & $\checkmark$ & \\
\hline
\end{tabular}


It may be seen that the predominant teaching sequence consists of Animating supported by both Translating and Explaining. Prompting appears in the above text in its rhetorical form, where the teacher posed several questions, appeared to anticipate no reply, and answered them herself. The alternation of languages and functions displayed in this brief text demonstrates a seamlessness in the bilingual discourse constructed by this teacher, and one which was apparent across the data collected in the study as a whole.

\section{CONCLUSION}

The question posed in this paper was:

What are the principal pedagogic functions of L1 and L2 teacher talk in this EFL context?

The study has offered a bilingual framework of teacher talk consisting of six pedagogic functions of Animating, Translating, Explaining, Creating, Prompting and Dialoguing which afford different kinds of learning opportunities specifically relevant to the bilingual classes experienced by many EFL (and FLL) students as follows.

Animating enables language learners to listen to L2 which is already 'anchored' in writing. This cross-modal experience may be considered unremarkable in ESL contexts, but in Thailand, and other situations of low/unreliable technology, the teacher's capacity to 're-channel' is vital for students' familiarization with the foreign tongue, and represents a key attribute of the teacher's professional status. Translating is clearly a pedagogic function through which communication can soar, with meaning rapidly and accurately conveyed, and a different classroom tenor afforded. It is ironic indeed that this use of L1 is precisely what has been dismissed by ESL orthodoxy. Explaining is of course a fundamental part of teaching. When conducted in L1, Explaining can be achieved in a swift, accurate and inclusive manner. When conducted in L2, it can additionally provide message-oriented teacher talk. Creating happens when teachers draw upon resources of semantics, lexicogrammar, or extra-linguistic semiosis in order to modify and contextualize L2 communication in ways that will render it more transparent and accessible to learners. Prompting and Dialoguing both offer means for the teacher to bring student responses into the picture.

Overall, the study shows how bilingual teacher talk represented a default pedagogy in this Asian EFL context. Through a functional analysis, it has been determined that judicious use of L1 in this context is both principled - there are readily discernible causes and effects of teacher language choice; and productive - the L1 serves as a resource for embedding new forms and meanings from L2. The categories devised here are intentionally broad enough to permit teachers to apply them in 
reflecting upon their own and others' lessons. It is hoped that they may assist in answering the kind of question succinctly put by Üstünel and Seedhouse (2005): 'Why that, in that language, right now?' Finally, an important caveat remains. In supporting the use of L1 in ELT, we do not wish to reduce the opportunity for maximum L2 use in the L2 classroom; and this is a view repeated without exception by writers who have reconsidered the role of L1 (e.g. Macaro 2001; Cook 2001; Butzkamm and Caldwell, 2009). However, here are bilingual learners, with bilingual teachers: clearly, the first language and culture already imbue the hearts and minds of both. A pretence that this is not so can only serve to devalue the potential of L1 as a learning resource which is profound, catalytic and unique.

\section{ACKNOWLEDGEMENT}

I would like to thank Ajarn Chitcharoen Satewerawat and Ajarn Sirinut

Sawatdeenarunat for their assistance in transcribing and translating the Thai texts presented here.

\section{REFERENCES}

Allen J, Fröhlich M and Spada N (1984) The communicative orientation of second language teaching. In: Handscombe J, Orem R and Taylor B (eds) On TESOL '83. Washington, DC: TESOL, 231-252.

Barnes D (1976) From communication to curriculum. Harmondsworth: Penguin.

Butzkamm W (2003) We only learn language once. The role of the mother tongue in FL classrooms: death of a dogma. Language Learning Journal 28: 4-14.

Butzkamm W and Caldwell J (2009) The bilingual reform: A paradigm shift in foreign language teaching. Tübingen: Narr Studienbücher.

Canagarajah AS (1995) Functions of code switching in the ESL classroom: Socialising bilingualism in Jaffna. Journal of Multilingual and Multicultural Development 16(3): 173-196.

Carless D (2008) Student use of the mother tongue in the task-based classroom. English Language Teaching Journal 62(4): 331-338.

Christie F (1994) On pedagogic discourse. Melbourne: Australian Research Council.

Cook G (2010) Translation in language teaching: An argument for reassessment. Oxford: Oxford University Press.

Cook V (2001) Using the first language in the classroom. Canadian Modern Language Review 57(3): 402-423.

Ellis R (2001) The metaphorical construction of second language learners. In: Breen M (ed.) Learner contributions to language learning. London: Longman, 65-85. 
Ellis R (2003) The study of second language acquisition ( $2^{\text {nd }}$ edition). Oxford: Oxford University Press.

Ferguson GR (2003) Classroom code-switching in post-colonial contexts: Functions, attitudes, and policies. In: Makoni S and Meinhof U (eds) Africa and Applied Linguistics, AILA Review 16. Amsterdam: John Benjamins.

Ferguson GR (2009) What next? Towards an agenda for classroom codeswitching research. International Journal of Bilingual Education and Bilingualism 12(2): 231-241.

Forman R (2005) Teaching EFL in Thailand: A bilingual study. Unpublished Ph D thesis, University of Technology Sydney (UTS).

Forman R (2008) Using notions of scaffolding and intertextuality to understand the bilingual teaching of English as a Foreign Language. Linguistics and Education 19(4): 319-332.

Forman R (2010) Ten principles of bilingual pedagogy. In: Mahboob A (ed.) The NNEST lens: Non native speakers in TESOL. Newcastle-Upon-Tyne: Cambridge Scholars, 54-86.

Forman R (2011) Humorous language play in a Thai EFL classroom. Applied Linguistics 32(5): 541-565.

Gass SM and Selinker L (2001) Second language acquisition: An introductory course. Mahwah, NJ: Erlbaum.

Gibbons P (2003) Mediating language learning: Teacher interactions with ESL students in a content-based classroom. TESOL Quarterly 37(2): 247-273.

Goffman I (1974) Frame analysis: An essay on the organization of experience. Cambridge, MA: Harvard University Press.

Halliday MAK (1985) Spoken and written language. Geelong, VIC: Deakin University Press.

International Journal of Bilingual Education and Bilingualism (2009) Special Issue 12(2): Conflicts and tensions in classroom codeswitching.

Kim SH (2001) Language alternation behaviour among native-speaking foreign language teachers in New Zealand secondary schools. Unpublished MA thesis, University of Auckland, NZ.

Kim SH and Elder C (2005) Language choices and pedagogic functions in the foreign language classroom: A cross-linguistic functional analysis of teacher talk. Language Teaching Research 9(4): 355-380.

Lemke JL (1990) Talking science: Language, learning and values. Norwood, NJ: Ablex.

Lin AMY (1996) Bilingualism or linguistic segregation? Symbolic domination, resistance and code-switching in Hong Kong schools. Linguistics and Education 8(1): 49-84. 
Liu D, Ahn G-S, Baek K-S and Han N-O (2004) South Korean high school English teachers' code switching: Questions and challenges in the drive for maximal use of English in teaching. TESOL Quarterly 38(4): 605-638.

Macaro E (2000) Issues in target language teaching. In: Field K (ed.) Issues in modern foreign languages teaching. London: RoutledgeFalmer, 171-189.

Macaro E (2001) Analysing student teachers' codeswitching in foreign language classrooms: Theories and decision making. Modern Language Journal 85(4): 531-548.

Myojin C (2007) The effect of teacher talk in EFL classrooms: The non-use or use of learners' L1 by an instructor. K@ta 9(1): 1-18.

Raschka C, Sercombe P and Chi-Ling H (2009) Conflicts and tensions in codeswitching in a Taiwanese EFL classroom. International Journal of Bilingual Education and Bilingualism 12(2): 157-171.

Richards JC and Sandy C (1998) Passages 1: Student's Book. Cambridge: Cambridge University Press.

Scott VM and De La Fuente MJ (2008) What's the problem? L2 learners' use of the L1 during consciousness-raising, form-focused tasks. Modern Language Journal 92(1): 100-113.

Sinclair J and Coulthard R (1975) Towards an analysis of discourse: The English used by teachers and pupils. London: Oxford University Press.

Song Y and Andrews S (2009) The L1 in L2 learning - Teachers' beliefs and practices. Munich: LINCOM Europa.

Spada N and Frölich M (1995) COLT - Communicative orientation of language teaching observation scheme: Coding conventions and applications. Sydney, NSW: NCELTR, Macquarie University.

Swain M and Lapkin S (2005) The evolving sociopolitical context of immersion education in Canada: Some implications for program development. International Journal of Applied Linguistics 15(2): 169-186.

Tsui A (1995) Introducing classroom interaction. London: Penguin.

Turnbull M and O'Daley-Cain J (eds) (2009a) First language use in second and foreign language learning. Clevedon: Multilingual Matters.

Turnbull M and O'Daley-Cain J (eds) (2009b) Introduction to First language use in second and foreign language learning. Clevedon: Multilingual Matters,1-14.

Üstünel E and Seedhouse P (2005) Why that, in that language, right now? Codeswitching and pedagogical focus. International Journal of Applied Linguistics 15(4): 302-324.

Watson-Todd R, Chaiyasuk I, and Tantisawatrat N (2008) A functional analysis of teachers' instructions. RELC Journal 39: 25-50.

Zacharias NT (2004) Teachers' beliefs about the use of the students' mother tongue. EA Journal 22(10): 44-5. 


\section{APPENDIX: TRANSCRIPTION CONVENTIONS}

Language

ก็พอ Thai

person English

house English translation

Intonation contours

. falling (statements and wh- questions)

? rising (polar questions and challenges)

, level/low rise (lists and continuation)

! rise/fall (intensity/animation)

\section{Pauses}

(3 sec) 3 seconds

... less than one second

but- speaker breaks off

\section{Metatranscription}

(??) unintelligible

(( )) [11 point italic font] researcher's comment on manner or meaning. 